\title{
REVISIÓN
}

\section{The development of a web page for lipid science and research. Main web sites of interest}

\author{
By A. Farran, J. Pascual ${ }^{\star}$, J. Grillo, R. Codony and J. Boatella \\ Unidad de Calidad Nutricional y Tecnológica de los Lípidos (Food Lipids, Quality and Health Unit). \\ Nutrition and Food Science Department, University of Barcelona-CeRTA \\ Avda. Joan XXIII s/n. 08028-Barcelona (Spain) http://www.ub.es/qnt//
}

\section{RESUMEN}

Desarrollo de una página web en ciencia de lípidos para investigación. Principales sitios de la web de interés.

En internet encontramos gran cantidad de información científico-técnica cuya validez no suele estar controlada por comités correctores. Para aprovechar estos recursos es necesario filtrar y facilitar el acceso del usuario a la información. En este artículo se expone la experiencia práctica en el desarrollo de una página WEB centrada en las actividades del grupo de investigación "Calidad Nutricional y Tecnología de los Lípidos". Los objetivos de esta página WEB fueron los siguientes: difusión de las actividades del grupo de investigación, aprovechar los recursos que ofrece internet y fomentar y facilitar su uso. Esta experiencia permitió presentar una metodología de trabajo eficaz para conseguir estos objetivos. Finalmente, se presentan un gran número de direcciones WEB agrupadas por apartados en el ámbito de los lípidos. Estas direcciones han sido rigurosamente seleccionadas, entre un gran número de referencias consultadas, siguiendo una serie de criterios que se discuten en este trabajo, para ofrecer aquellas que presentan un mayor interés práctico.

PALABRAS-CLAVE: Ciencia de lípidos - Internet - Página web - Revisión (artículo) - Sistemas de información.

\section{SUMMARY}

The development of a web page for lipid science and research. Main web sites of interest.

Internet provide access to a huge of scientific and technical information on Internet which is not validated by any committee of experts. This information needs filtering in order to optimize user access to these resources. In this paper, we describe the development of a WEB page outlining the activity of our research team Food Lipids Quality and Health. The WEB page seeks to fulfil the following objectives: to communicate the activities of the team, to use effectively the resources that Internet offers and to promote their use among the team. We report on the methods used in achieving these objectives. Finally, a large number of WEB addresses related to Lipids are presented and classified. The addresses have been selected on the basis of their usefulness and interest value.

KEY-WORDS: Information systems - Internet - Lipid science Review (paper) - Web page.

\section{INTRODUCTION}

Internet is an international computer network with a common communication protocol which manages a flow of large volumes of information. It enables any individual anywhere in the world to connect up to this network via his personal computer, at any time during day or night and to communicate with any other user wherever he might be (Thomas, 1996). In the initial stages of its development, Internet was used by universities to obtain scientific information and to establish contact between scientists and professors. In the meantime, Internet has become a powerful channel via which enterprises can market and sell their products. Internet today has grown enormously (Figure 1) and users have come to appreciate the great advantages of the system. Access to electronic information and its management is increasingly shifting and from the hands of experts to those of the users. Today, users are playing a much more active role (Anonymous, 1997).

There are three modes of communication via the electronic net. First, and most tipically, is the one-to-one communication mode. Second, there is the one-to-many communication mode, which can be restricted (one way) or open in nature, as in a round table. Finally, there is access to different types of information resource, such as data file systems, libraries, journals, TV programmes, live presentations, etc., known as data bases. In each of these communication systems, the transferred information can be audio, visual, or even tactile (McLellan, 1995). A very wide set of tools are available for the various modes of electronic communiction. E-mail is obviously the best known and most used tool. Today, $80 \%$ of Internet communications are via e-mail (Anonymous, 1997). It is also possible to access newsgroups, where users can post news, items, questions or comments on a specific subject. This is known as usenet and it accounts for about 15\% of total Internet applications (McLellan, 1995). Those users suscribing to a listserv can send and receive up-dated information on any subject of interest to them. The listserv is managed by an 
owner, who can choose to make it public or private. The listserv can obtain a regulated or unregulated list which allows the owner to control access to the listserv. This tool has particularly useful applications in the area of scientific communications. Real time conversations can be held by two or more users simultaneously through the Internet Relay Chat (IRC). Finally, mention should be made of Internet videoconferencing, which currently has not been fully developed, but with will be of considerable importance in the future of scientific communications: attending workshops and meetings, remote teaching, sharing images, direct consultations with experts, professional communications, etc (Anonymous, 1997). Access to available information on the servers connected to an electronic network can be gained in a number of ways, including the File Transfer Protocol (FTP), Gopher and the WEB. The FTP allows computer files to be transfered from a remote server to the PC or viceversa. Gopher is a tool designed to facilitate access to available information located on computers conected to Internet, through a hierarchical menu system. The WEB is a similar service, but it uses hypertext technology which simplifies the access to available information.

Table 1 shows the main advantages and disadvantages of Internet as a communication tool (Thomas, 1996; Anonymous, 1997; Stewart, 1995).

\section{Table 1}

\section{ADVANTAGES AND DISADVANTAGES OF INTERNET USAGE}

\begin{tabular}{l} 
Advantages \\
\hline - Availability of mainly free information \\
- Low cost of initial connection \\
- Reduces the costs of divulgation \\
- The same protocol of communication can be used for all the \\
services \\
- Facilitates rapid interactive communication \\
- Facilitates the exchange of huge volumes of data \\
- Facilitates the establishment of professional contact \\
- No barriers to divulgation \\
- Facilitates access to different sources of information, which \\
is continously up-dated \\
- Facilitates management of companies information system \\
- It is accesible from anywhere \\
- It has become the global media \\
\hline
\end{tabular}

- Danger of overload and excess information

- It requires an efficient information search strategy

- The search can be slow

- It is difficult to filter and prioritize information

- No guarantee of finding what one is looking for

- There is a lot of apparently unconnected information

- Net becomes overloaded because of large number of users

- No regulation

- No quality control over available data

- The ease with which information can be constantly up-dated can cause problems of referencing
WEB has established itself as the most useful system on Internet and has emormous possibilities for the future given its ease of reading (good visual design), ease of consulting (good logical organization) and ease of searching (flexible search system). Its only shortcoming is the restricted amount of information that can be included to ensure user comfort at the moment of reading (Morgan, 1995; Matthaeus, 1998; Schlotke, 1996). This highlights the need to optimize the system, overcoming this disadvantage. The handling of large amounts of information requires a considerable effort in several aspects: defining clearly and concisely the information wanted; familiarization with the characteristics of the tools to be used; and the following of methodical protocols. In this way, we can avoid excess information and minimize the time need to obtain it (Blanchfield, 1996). More specifically, there are various services and software on the net for carrying out the information search, known as searching engines (Yahoo, Excite, Altavista, WebCrawler, Dónde?, Olé!; Archie, etc.). These searching engines can only be used when users understand well search procedure, which can vary from service to service. When the search is completed, the use of filters is recommended to sift out irrelevant material. These filters are still not very well developed, but can be obtained from specialized software, the suscribing services need for up-dating Internet information or through email consultant services. The main conclusion that can be drawn is that an optimized protocol must always be used for Internet search (McLellan, 1995).

In short, the way we handle the information is as important as the information itself. If we want to use the information efficiently, we must learn to select, guide and control the flow of information, in order to maximize our benefits (Anonymous, 1997). Our research team, working in the field of lipid science, has planned the design of a WEB page that seeks to fulfil the following objectives. First, we have saught to create a tool for communicating the scientific research work of our team, and then, to create a database of public interest for lipid scientists. The main objectives were: a) the diffusion of the activities of the research team (Lipids, Food Quality and Health Unit) at the University of Barcelona, using Internet as a vehicle to communicate with scientists and other professionals in the field of the lipids and lipid foods; b) to exploit the scientific and technical resources available on Internet in our field, mainly by facilitating and optimizing the search for specific information by team members; and c) to promote and facilitate the use of Internet in our daily work.

\section{MATERIAL AND METHODS}

First, we used the scientific and technical literature written by the experts in Food Science and 
Nutrition and those in Documentation. This establishes the basis for Internet use and provide some interesting addresses that are specialized in search strategies, WEB page design and software edition.

To carry out our work, a $8 \mathrm{Mb}$ RAM Pentium (Windows 3.11) was used, connected to a server at the University of Barcelona (farmacia.far.ub.es). Netscape 4.01 was used as a client programm to gain access to Internet services, which can be obtained from the Netscape web page. This includes a powerful web-page editor (Netscape Composer). To keep, store and classify the web page addresses that might be of interest, the Netscape bookmark option was used, since it allows a web page containing the stored addresses to be automatically generated. When the number of addresses to be handled is very high or when a very complex classification is required, the use of a data base manager (e.g. Access, etc.) is recommended. The usual searching engines present on the net (Yahoo, Altavista, WebCrawler, etc.) were used to find those web pages that might be of interest in the field of lipid sciences and technology. In order to classify, and also discard, the very large amounts of information, we needed to establish a general organization with different subgroups, where the new web addresses could be listed. This classification (table 2) was adopted after consulting the main indexes for food/lipid science and technology. In additon, we used our previous experience in this field, working with the literature classification drawn up by our research team for internal use. In the search process, a basic tool is obviously the key words list which will orientate any specific search. Clearly the key word must not be too general, because it might lead to a large proportion of irrelevant information (e.g., the use of the key word cholesterol, could result in a list of addresses that includes scientific international organizations, commercial enterprises, nature associations, university departments, and many other types of web page). At the same time, the key word used should not be too specific, as they might lead to the recovery of overly restricted information, missing some interesting addresses on the defined subject. Therefore, a suitable combination of a small number of key words must be used in order to adapt to the field of search. Indeed, the searchers themselfs offer modern and powerful help tools, through logical connectors (and, or, not, near, etc.) which allow the user to specify the main key words. Below, we give some examples:

- oxyesterols AND atherosclerosis

- cholesterol AND coronary AND heart AND disease

- (polyunsaturated OR monounsaturated OR saturated) AND fatty AND acids

- trans AND fatty AND acids AND lipoproteins
- (beta-carotene OR vitamin E) AND free AND radicals

We first surfed the net in order to visit the web page addresses that we had listed from a previous review of the scientific and commercial literature. Then we searched and visited the web pages corresponding to the main institutions, book and journal editors, etc. Finally, through the searchers above cited, and using the key words list, we searched any new interesting adresses to complete the areas in the general classification (see table 2). For selecting and recording the eventual addresses the following criteria were applied:

a) the reputation of the institution/enterprise publishing the page

b) the principal nature of the page (commercial, scientific or informative)

c) the value and originality of the content

d) the frequency of information up-dating

e) the supervision of content by advisory committees

f) the scores given by the searching engines to the addresses in relation to the keyword used

The addresses were then classified in the subgroups as previously defined, aceording to the main orientation of the web page and its characteristics. Due to the large number of addresses, all the information collected was entered on to a data base for case of handling. This data base manager also enabled us to transfer the information to the web page, using the HTML format. Before this transfer, a filtering process was applied in order to check the validity of the addresses and any possible deffects of a formal nature. First, we checked for any repeated or unsuitable addresses (difficult or impossible access) or incomplete addresses. We also checked contents for information about human resources (contact with other research groups, information interchange), bibliographic resources (library catalogue consultation, electronic journals, reports offered by different organisms, etc.)

Table 2

\section{GENERAL CLASSIFICATION OF THE WEB ADDRESSES OF INTEREST}

ANALYSIS AND QUALITY CONTROL

FOOD SAFETY AND TOXICOLOGY

FOOD TECHNOLOGY

Preservation and stability

Fat replacers

HEALTH

Technical processes and biotechnology

INDUSTRIES

JOURNALS AND PLIBLISHERS

LIBRARIES AND DOCUMENTATION

LIPID CHEMISTRY AND FOOD COMPOSITION

Specific foods

Food composition

Lipid compounds

NORMALIZATION AND REGULATIONS

NUTRITION AND DIETETICS

UNIVERSITIES AND R+D CENTERS 
and material resources (acquisition of equipment and reagents, software, standards,etc.). Finally, we edited the web page, using Netscape Composer (although many other simple editors are available now on the market), according to the following guidelines. The page should be:

- clear (syntactical and semantic review)

- concise (maximum information occuping the minimum place)

- ordered (easy access and user friendly)

- universal (using one or more international languages)

- linked with other pages

- contain only essential images (since they occupy many bytes and slow down access to the page)

Edited and located on the server, the page must be actively diffused, using different means, such as specialized distributors, use of listservs, register at searchers, etc.

\section{RESULTS}

\subsection{Activities undertaken by the research team (FLQH)}

The first section of the page includes the main data and activities of our research team, Food Lipids, Quality and Health, providing information about: a) lines of research; b) members of the team (with electronic addresses); c) main publications and communications; d) main projects; and e) relationships with other research teams in the world. This allows, via e-mail, contact to be established with other researchers working in the same field and information, papers, etc. to be exchanged more easily.

\subsection{Evaluation of web pages included in our data base}

Annex 1 shows the list of the main Internet addresses classified in accordance with our criteria. The content of each group in this classification is discussed below.

INDUSTRIES. Addresses of enterprises working in different food sectors (raw materials, food products and services), and particularly in the field of oils and fats, antioxidants and fat foods. The American Oil Chemists Society page offers an exhaustive directory of fat and of producing and distributing enterprises. Also, the Thomas Food Industry Register contains a good directory of food industry professionals.

UNIVERSITIES AND R+D CENTERS. Addresses of groups at universities and other research centers working in lipid related subjects, such as lipid metabolism, lipid technology, meat and dairy products, extraction and purification of oils and fats, rancidity in foods, antioxidants, food hygiene and quality, and many others. These pages contain information about projects, papers, reviews, etc. The University of Minnesota has a very good page specialized in lipids.

LIBRARY AND DOCUMENTATION. Sites edited by libraries and documentation services which allow users to consult their publication catalogues, statistical information, library directories and a great number of other connections in the food and lipid field. Many sites offer documental information about web addresses, such as The Martindale's Health Science Guide, the US Department of Agriculture page or the FAO and OMS sites.

HYGIENE AND TOXICOLOGY. Reports about microbiological and toxicological aspects of fats and fat foods, their staling and preservation. It also includes data bases reporting information about the main patogen microorganisms and toxic substances, legal regulation and activities concerning food safety committees. Very interesting information can be found at the US Food and Drug Administration site, The National Food Safetty Database, The Office of the Chief Veterinary Officer. More specific information about the control of residues in food products can be found at the site of the University of Florida, and The Oxygen Club of California site offers the most complete information about free radicals in biological systems.

FOOD TECHNOLOGY. This includes 3 differents chapters: Stability and Preservation, Processes and Biotechnology and Fat Replacers. The first of these includes reports on preservation systems and conditions, the use of additives, and packing processes and materials. The second includes reports on frying process and their control, modification of the fat fraction in foods and also includes teaching material on lipid technology (Paul Singh's page is particularly interesting). It also includes reports on the biotechnological modification of fat composition in raw materials, as well as the directories of the main biotechnological centers. The Institute of Food Research page gives complete and up-dated information about biotechnological applications in fat and oil production. The third chapter includes reports on olestra and its food applications, safety and legal regulation. It contains also reports on other fat replacers and their applications. The Institute of Food Science and Technology and the Food and Drug Administration pages are the most complete in this field.

NUTRITION AND DIETETICS. Reports and guides on reducing fats in diet and on fat replacers. On-line programms to calculate the basic metabolic rate and the nutrient supply from a diet. Reports, data bases and information about lipid metabolism and fatty acid synthesis. The International Food Information Council page gives information about physiological effects of dietary fats. The University of 
Yale page includes a data base on metabolic pathways. Another interesting page on Nutrition and Dietetics is that edited by The American Dietetic Association.

HEALTH. Information about effects of consumption of different fat types and components (cancer, coronary heart disease, diabetes). Nutritional recommendations concerning fats in the diet. Reports on food habits in different populations and epidemiological significance. Food Pyramid and other dietetic guides and their applications in nutritional and health education. The most interesting page in this field is the FDA page. The Scientific and Industrial Research for Australia (CSIRO) page gives interesting and detailed information about relationships between antioxidant vitamins, lipids in the diet and disease prevention.

JOURNALS AND EDITORS. A selection of 33 addresses that give access to the main editors of journals, books and manuals, as well as direct access to a number of specialized journals. The addresses selected cover the whole field of lipid science and technology with references covering subjects from fat and oil composition data, technology of fats to nutritional, toxicological and health repercussions. In most cases summaries of articles are available and, in some cases, the whole article. Many of the editors include additional electronic services. One of the most interesting pages in this chapter is The American Oil Chemists Society page.

STANDARDIZATION AND LEGISLATION. These addresses provide access to Spanish and international institutions working in the standardization and/or legislation of fats and oils (BOE, DOGC, CODEX, SO, etc). Also included are associations and institutions that accredit or certify products or enterprises/organizations (AENOR, LGAI, AOAC, etc). The Foodnet Canada page is very interesting since it compiles up-dated food legal norms from USA and Canada. The most interesting page in this field is the CODEX page, which gives the most diversified information: reports of all the Committee meetings, data base of maximum limits of residues in foods, HACCP guidelines, labelling guidelines, etc. The FDA and $A A F C$ pages are also interesting in the field of food labelling.

QUALITY CONTROL AND ANALYSIS. This includes 30 addresses of interest for food analysts. First, there are addresses of the main suppliers of material, reactives, standards and other laborartory instrumentation, which enable users to obtain information, catalogues and to order via Internet. Some organizations' pages also give information about analytical methodology, validation procedures and teaching material.

CHEMISTRY AND COMPOSITION. This includes three chapters. First, there is a chapter dealing with food composition, which includes scientific reports and on-line data bases, which can be downloaded from your own PC. The main pages in this field are the databases given by the USDA and the Swiss Food Composition Database. A second chapter includes specific pages on lipid composition, dealing with essential fatty acids, n-3 fatty acids (EPA and DHA), liposoluble vitamins, carotenoids, sterols, etc. Some of these pages give very complete and detailed information about individual components, such as the Trans Fat Info Web (trans fatty acid structures, presence in food, consumption, etc). The third chapter includes information on specific fatty foods, such as fish, nuts, meat products, milk products, and other manufactured products.

Different aspects have been considered ranging from nutritional composition to technologies of elaboration or consumption and production statistics. Obviously, a large number of addresses (23) deal with edible oil and fat composition and production.

\section{CONCLUSIONS}

The scientific and technical information available on Internet is not subjected to the analysis of editorial commitees. For this reason, the reputation of the institution/organization that edits the web page is perhaps the most important reference we have. In fact, this criterion is very useful for filtering the large volumes of information available in any field and was one of the most important in designing our page. However, this lack of such committees makes Internet a more dynamic tool and facilitates the up-dating of information on a web page. In this way, the communication between teams working on similar projects is greatly enhanced without their having to attend meetings or congresses. In contrast, in relation to methods need and results obtained, a considerable problem is still to be overcome: namely the confidentiality of Internet data. Internet has also become the most powerful way of accessing bibliographies (library catalogues, electronic journals consultation, etc) and material resources (purchase of equipment, standards and reactives, documents and books, raw materials, software, etc). However, perhaps the most important aspect of Internet is the possibility it provides of making on-line database consultations and immediate exchange of information. The future development of Internet will allow users to access more easily and more rapidly to the above mentioned resources, but it also will require the development of efficient mechanisms to evaluate and filter the scientific and technical information. Furthermore, it will require users to be more critical with information in all cases. Finally, the number of web pages appearing on the Internet grows each 
day as the software becomes cheaper and more simple to use.

\section{BIBLIOGRAPHY}

Anonymous (1997). The internet and analytical chemists: resources and strategies. Inform, 8 (10). 1030-1045.

Blanchfield, J.R. (1996). Food science and technology on the Internet. Trends Food Sci. Tech., 7, 1-8.

Gromov, G. R. (1998) History of Internet and WWW: The Roads and Crossroads of Internet History. http:// www.intemetvalley.com/intvalstat.html.

Matthaeus, B. (1998). Using information systems of the Internet in the field of food and nutrition sciences. Deutsche-Lebensmitel-Rundschau, 94 (8), 256-262.

McLellan, M.R. (1995) Electronic information management: a model for industry academia and IFT. Food Technol., $3,74-81,96$.
Morgan, E.L. (1995). Using World Wide Web and WAIS technologies to create electronic information systems. J. Agric. Food Inform., 3 (2), 3-11.

Schlotke, F. (1996). Using Internet services to improve international food data exchange. Food Chem. 57 (1), 137-143.

Singh, R.P. (1996). Teaching food science and technology on the World Wide Web. Food Technol., 3, 94-99.

Stewart, K.K. (1995). Food composition data and the World Wide Web. Part II: an overview. J. Food Comp. Anal., 8, 299-300.

Thomas, k. (1996). On-line information: selecting your source. IFI, 4, 49-52.

\section{ANNEX 1}

\section{ANALYSIS AND QUALITY CONTROL}

American Chemical Society

American National Standards Institute (ANSI): ANSI Catalog

American Society for Testing Materials

AOAC: Methods validation and technical programs

Chemexpert

Chemical Analysis Zorbax HPLC Columns

Chrompack

J\&W Scientific

National Institute of Standards and Technology

Sigma-Aldrich

The American Oil Chemists Society: AOCS Methods

U.S Pharmacopeia

University of Akron: Dept. of Chemistry: The Hardy Research

Group: The Virtual Classroom

\section{FOOD SAFETY AND TOXICOLOGY}

Agency for Toxic Substances and Disease Registry: Cornell University: Pesticide Residues an Enviromental Contaminants.

Institute of Food Research (IFR): Science at IFR: Cut microbiology and health

Ministry of Agriculture, Fisheries and Food: Department of

Health: Food Safety: Guidance the food safety Regulations 1995

Office of the Chief Veterinary Officer

Oxygen Club of California

Oxygen Society

The Eduzone: Oxidative Rancidity

The National Food Safety Database:

U.S Food and Drug: Administration Food Imports: Imports Alerts

U.S. Food and Drug Administration Centre for Food Safety and Nutrition

University of Florida: Residues Methods Database

University of lowa: Food Microbiology: Section I and II

University of Nebraska: The Food Safety webside: Foodborne illnesses

University of Purdue: Publications: Retail food safety (Issue 1)

University of Vermont: Course Manual: HACCP, Regulation

Nutrition, Good Manufacturing Practices, Regulation of food sanitation. http://www.acs.org

http://web. ansi. org/default. htm

http://www. astm. org/

http://www. aoac. org/techprog/menu. htm

http://www. chemexper be/

http://www.zorbax.com/

http://www. chrompack. com/index. htm

http://www.jandw. com/

http://www. nist. gov/

http://www.sigma-aldrich.com/

http://www. aocs. org/method 1 . htm

$\mathrm{http}: / /$ www. usp. org/

http://ull. chemistry. uakron.edu/

Recibido: Diciembre 1999 Aceptado: Julio 2000 http://atsdr1. atsdr. cdc. gov:8080/atsdrhome. html http://www. nysaes. cornell. edu/fst/market/pestic. html

http://www. ifrn. bbsrc. ac. uk/buscom/ar96/microbiology. html http://www.open.gov.uk/doh busguide.htmt/\#food-safety

http://www.dpie.gov.au/ocvo/ http://radicals.berkeley.edu/ http://www.biophysics.mcw.edu/oxsoc/

http://www.eduzone.com

http://www.foodsafety.org

http://www.fda.gov/oral/fiars/ora-imports.alerts.html

http://vm.cfsan.fda.gov/list.html

http://fshn.ifas.ufledu/index.htm http://www.public.iastate.edu/ burcu/fdmicro.html http://foodsci. unl.edu/fstfpc. asp

http://www.foodsci.purdue.edu http://nuts. uvm. edu/nusc237/MANUAL. HTML 
Wisconsin Center for Dairy Research:

\section{FOOD TECHNOLOGY - Fat replacers}

American Dietetic Asociation (ADA): Hot Topics

American Heart Association: Olestra

Calorie Control Council

Canola Council of Canada

Fritolay

Institute of Food Science and Technology (IFST): Olestra

International Food Information Council: Fat-Replacers

Ohio State University: Olestra

OLEAN

U.S. Food and Drug Administration Centre for Food

Safety and Nutrition: Areas programs: Food additives

and Premarket approval: Olestra backgrounder

University of Oregon: Low fat products, fat replacers,

fat substitutes, reduced fat

University of Vermont: Olestra

\section{FOOD TECHNOLOGY - Preservation and stability}

CSIRO Division of Human Nutrition: Food Processing Sector Foodservice \& Packaging Institut: Product directory

U.S. Food and Drug Administration Centre for Food Safety and Nutrition: Questions and answers: Food additives

VTT Biotechnology and Food Research: Microbiology Safety: http://www.vtt.fi/bel/mib/index.htm Hygiene, Mineral processing and Packaging

\section{FOOD TECHNOLOGY - Technical processes and biotechnology}

Agriculture and Agri-Food Canada: AGTRAN

Agriculture and Agri-Food Canada: ICAR

CSIRO Division of Human Nutrition: Press Research "Fear of Frying"

Foodnet Canada: Biotechnology

Genox Corporation

Institute of Food Research (IFR): Science IFR: Materials and Ingredients/Gene Technology for Food Quality

Instituto de Biotecnologia de Granada

International Food Information Council: Food Biotechnology

Paul Singh's On-line Food Engineering Teaching Course.

Seedoil Modification Group

University of Guelph: Office of research: Happiness up milk fat down.

University of Illinois: Food Equipment

University of Oregon: Science of foods: NFM235 Lipid

emulsion

University of Oregon: Emulsions

VTT Biotechnology and Food Research: Biotechnology

\section{HEALTH}

American Dietetic Asociation (ADA): Nutrition Surrey

American Dietetic Asociation (ADA):

American Heart Association: Dietary Guidelines For Healthy

American Adults

Calculate the cardiovascular risck of your patients calaculator CSIRO Division of Human Nutrition: Factsheets "Antioxidants and Coronary Heart Disease"

CSIRO Division of Human Nutrition: Functional Foods

CSIRO Division of Human Nutrition: Factsheets "Diet and

Cancer risk"

Department of Pathological Biochemistry in Glasglow

University: Cardiovascular Research in Pathological

Biochemistry.GRI

Food \& Nutrition Information:

International Food Information Council: Adult Nutrition Health http://www. cdr. wisc.edu/Home.html

http://www.eatright.org.

http://www. amhrt. org/

http://www.caloriecontrol.org

http://www.canola-council.org

http://www. fritolay. com/

http://www. easynet. co. uk. 80/ifst/hottop 13. htm http://ificinfo. health.org/index 7.htm

http://www.acces.spo.gov/su doc/acces/acces $140 \mathrm{htm}$ http://www.olean.com/

http://www.cfsan.fda.gov/list.html

http://www.orst.edu/food-resource/index.html

http://www.uvm.edu/

http://www.csiro.au/csiro/structure/food.htm http://www.fpi.org/proddirtoc.html

http://vm.cfsan.fda.gov/ dms/qa-top.html

http://www.agr.ca/research/agtran/agt_ole.html http://www.agr.ca/icar/icarhome.html http://www.dhn.csiro.au/prfrying.html

http://foodnet.fic.ca/biotech/farm2.html http://www.genox.com/

http://www.ifrn.bbsrc.ac.uk/buscom/ar96/

http://aggranados.ugr.es/biotec.htm http://ificinfo.health.org/index14.htm $\mathrm{http}: / /$ nachos.engr.ucdavis.edu/ rpsingh/index.htm http://www.pbi.nrc.ca/seedoil.html

htp://www.uoguelph.ca/Research/

http://www.aces.uiuc.edu/ foodlab/equip/ http://www.orst.edu/instruct/nfm235/lipids/index.html

http://www.orst.edu/instruct/nfm235/food-systems/index.ht http://www. vtt.fi/bel/bio/index.htm

http://www.eatright.org/ http://www.eatright.org/ http://www.americanheart.org/Heart_and_Stroke_A Z Gui

http://www.hbroussais.fr/Scientific/ http://www.dhn.csiro.au/radio2.html

http://www.csiro.au/csiro/progl.html http:www.dhn.csiro.au/radio3.html

http://www.gla.ac.uk/Acad/PathBio/lipidresearch.html

http://www.monash.edu.au/IUNS/food\&nut-info.htm http://ificinfo.health.org/index2.htm 
National Cattlemen's Beef Association: Eating in American Today

The Surgeon of the Public Health Service. Health and Nutrition:

Trans Fat Info Web Page: The USDA Prespective on fats and oil 3 Decades ago.

Trans Fat Info Web Page: Fat Consumption

Trans Fat Info Web Page: The Industrial Revolution for fats and oils began 1910

Trans Fat Info Web Page: Food Fat Production and Eating Habits in late 1800s

U.S Deparment of Agriculture Food and Nutrition Information Center: Food guide pyramid information.

U.S Deparment of Agriculture Food and Nutrition Information Center: Information produced by other USA agencies: Dietary guidelines for americans

U.S Deparment of Agriculture Food and Nutrition Information Center: Healthy eating index

U.S Food and Drug: Alternatives to high-fat foods (FDA)

U.S. Food and Drug Administration Centre for Food Safety Nutrition: Information about nutrition: Women and nutrition.

U.S. Food and Drug Administration Centre for Food Safety and http://vm.cfsan.fda.gov/ dms/fdafiber.html Nutrition: Information about nutrition: Backing up fiber is healthful regulation.

U.S. Food and Drug Administration Centre for Food Safety and http://vm.cfsan.fda.gov/ dms/fdapound.html Nutrition: Using the food label: To loss weight

U.S. Food and Drug Administration Centre for Food Safety and http://vm.cfsan.fda.gov/ Ird/cons1194.txt Nutrition: Using the food label: To cope with diabetis

U.S. Food and Drug Administration Centre for Food Safety and http://vm.cfsan.fda.gov/ dms/fdheart.html Nutrition: Using the food label: To prevent the heart disease.

University of Texas: Fat intake continues to drop, veggies University of Vermont: Vit $\mathrm{E}$ and Coronary heart disease

\section{INDUSTRIES}

American Meat Institute: At Your Service

Asociación de Industrias de la Carne de España (AICE): Sector Cárnico

Food and Drink on Line

National Cottonseed Products Association: Directory of

Manufacturers and Suppliers of Cottonseed

National Oilseed Precessors Associations (NOPA): Exporters

The American Oil Chemists Society: AOCS Online Buyers Guide

The Food Marketing Institute: Food Industry information: Minority Vendor listing

The University of Minnesota Omega 3 and 6 News On Line: Industry

Thomas Food Industry Register: Database

Vitamin Express

\section{JOURNALS AND PUBLISHERS}

American Chemical Society: Publications

American Journal of Clinical Nutrition

American Society for Clinical Nutrition

American Society for Nutritional Sciences

AOAC: Publications

Clinical Nutrition and Metabolic Care

CSIRO Division of Human Nutrition: Publications

Elsevier Publications

European Journal of Clinical Nutrition

Food and Agricultural Inmunology

Food Chemistry

Food Microbiology

Food Science and Technology http://www.beef org/

http://www.mosptlight. org/media/reports/

http://www.enig.com/0001t15html

http://www.enig.com/0001t13.html http://www.enig.com/0001t12.html

http://www.enig.com/0001t11.html

http://vm.cfsan. fda.gov/ Ird/con0695.txt

http://www.nal.usda.gov/ dms/nutguide.html

http://www.nal.usda.gov/fnic/HEl/HEl.html

http://vm.cfsan.fda.gov/ dms/fdspdiet.html

http://vm.cfsan.fda.gov/ dms/wh_toc.html

http://www.usda.gov/news/releases/1 996/01/0024/ http://www.uvm.edu/ dklun/237pap.htm

http://www.meatami.org/svc.htm

http://sun20. cestel.es/aice/

http://www.foodanddrink.co.uk/

http://www.cottonseed.com/feedprod.htm

http://www.oilseeds.org/nopa/Exporter.html http://www.aocs.org/obgmain.htm

http://www.fmi.org/industry/mcl/index.html

http://pufa.co.net/industry.html

http://www. tfri. com/

http://www.vitaminexpress.com/

http://pubs.acs. org/new/newindex.html

http://www.faseb.org/ajcn/

http://www.faseb.org/ascn

http://www.nutrition.org/

http://www.aoac.org/pubs/pubshp.htm

http://www.lrpub.com/

http://www.dfst.csiro.au/

http://www.elsevier.nl

http://www.stockton-press.co.uk

http://www.bdt.org.br/bioline/fi

http://www.elsevier.nl/inca/publications/store/4/0/5/8/5/7/

http://www.hbuk.co.uk/ap/journals/fd/

http://www.hbuk.co.uk/ap/journals/fs/ 
INFOODS: Journal of Food Composition and Analysis Institute of Food Research (IFR): Publications Institute of Food Science and Technology (IFST): Journals Instituto de la Grasa de Sevilla: Publicaciones: Grasas y Aceites

Nature

New England Journal of Medicine

Nutritional Medicine

Oxygen Society: Free Radical Biology and Medicine

Royal Veterinary \& Agricultural University: Food Technology

The American Oil Chemists Society: Journal of the American

Oil Chemists Society

The American Oil Chemists Society: Lipids

The American Oil Chemists Society: AOCS Press and

Publications

The American Oil Chemists Society: Inform

The British Medical Journal

The Journal of Nutrition

The Lancet

\section{LIBRARIES AND DOCUMENTATION}

Agriculture and Agri-Food Canada: AAFC Publications

Canadian Institute of Fisheries Technology: Library

CSIC: CSIC: Servicio de publicaciones

CSIC: Servicio de Documentación

Chipsbooks: Oils and Fats

FAO: Library

Foodnet Canada:

Fuente de Estadsticas: Estadsticas Nutricionales

Healthlink: Supplement Library

Institute of Food Science and Technology (IFST): Food-related Mailing List and Newsgroup on Internet

Institute of Food Technology

Instituto de Agroquímica y Tecnología de Alimentos: Servicio

de Documentación i Biblioteca

International Food Information Council

Knight-Ridder Information-Science Base

Leatherhead Food Research Asociation. UK.: Databases

Foodline.

Martindale's Health Science Guide

TNO Nutrition of Food Research: TNO Corporate

U.S Deparment of Agriculture Food and Nutrition Information

Center: Food and nutrition information center publications and databases

World Health Organization: Finding information at WHO

http://www.apnet.com/www/catalog/index.htm http://www.ifrn.bbsrc.ac.uk/BUSCOM/publications/ http://www.easynet.co.uk/ifst/ http://www.ig.csic.es/revisi.htm

http://www.nature.com

http://www.nejm.org

http://www.bdt.org.br/bioline/nm http://www.elsevier.nl.80/inca/publications/store/5/2/5/4/6/9/ $\mathrm{http}: / /$ newton.foodsci.kvl.dk http://www.aocs.org/jaocs.htm

http://www.aocs.org/lipds1.htm http://www.aocs.org/press $1 . h t m$

http://www.aocs.org/itoc997.htm http://www.bmj.com

http://www.nutrition.org/

http://www.thelancet.com/

http://www.agr.ca/csb/pub/intr.5238.html

http://www.tuns.ca/

http://www.csic.es/publicu/

http://www. cindoc. csic. es/

http://www. chipsbooks. com/

http://www. fao. org/LIBRARY/DEFAULT.HTM

http://foodnet.fic.ca

http://www.festadisticas.fguam.es:80/

http://www.healthlink.com.au/

http://www. eaynet. co. uk/ifst/mailnews.htm

http://www.ift.org

http://www.iata.csic.es/

http://ificinfo.health.org

http://dialogselect.com

http://www.lfra.co.uk/lfra/database.html

http:www.-sci.lib.uci.edu/HSG/Nutrition. html http://www. voeding. tno.nl/fnic/software/software.html http://www.nalusda.gov/fnic/pubs_and_db.html

http://www-pll.who.ch/

\section{LIPID CHEMISTRY AND FOOD COMPOSITION - Food composition}

COST-99/EUROFOODS: Research Action on Food

Consumption and Composition Data

First Databank Nutrition Products

INFOODS: Base de dades

Nutribase

Swiss Food Composition Database

U.S Deparment of Agriculture Food and Nutrition Information

Center: Nutrient Data Laboratory

University of Illinois: Nutrient Analysis Tool

University of Texas: Nutrición Humana WEB http://food. ethz.ch/cost99/

http://www. firstdatabank. com/ http://www.crop.cri.nz/foodinfo/infoods/infoods.html http://www.nutribase.com http://food.ethz.ch:2000/home.html

http://www.nal.usda.gov/fnic/foodcomp/ http://www.ag.uiuc. edu/ food-lab/nat/ http://spin.com.mx/ jledesma/

\section{LIPID CHEMISTRY AND FOOD COMPOSITION - Lipid compounds}

Institute of Food Science and Technology (IFST): Trans Fatty Acids

Nordic Naturals Omega 3 and Pro Omega Related Research The University of Minnesota Omega 3 and 6 News On Line Trans Fat Info Web Page: Health Issues and Trans fat http://www.easynet.co.uk/ifst/hottop9.htm

http://www.nordicnat.com/proomega.htm http://pufa.co.net/ http://www.enig.com/0001t1a.html 


\section{LIPID CHEMISTRY AND FOOD COMPOSITION - Specific foods}

Agriculture and Agri-Food Canada: Database

Agriculture and Agri. Food Canada: Animals Poultry Layer

American Egg Board: Fowl \& Poultry Science

American Lamb Council

American Meat Institute

American Soybean Association

Asociación de Industrias de la Carne de España (AICE):

Asociación de Industrias de la Carne de España

Canada Beef Export Federation: Grow \& Structure of Meat animals

Canadian Institute of Fisheries Technology

Corn Refiners Association: Corn Oil

Food Dictionaries General: Food lover's Glossary

German Society for Fat Science

Instituto de Estudios del Huevo

International Fishmeal \& Oil Manufacturers Association

Japan Oil Chemist's Society (JOCS)

Kansas Soybean Association

Medaccess Corporation

Medilife

MHR Viandes

National Cattlemen's Beef Association

National Cottonseed Products Association

National Institute of Oilseed Products

National Pork Producers Council

Oilseeds Homepage

Olivanet

Palm Oil Research Institut of Malaysia (PORIM)

Poultry Science Association

Purdue Pork Page

The Scottish Dairy Association

U.S. Food and Drug Administration Centre for Food Safety and Nutrition: Fish, Meat and Poultry Dictionaries

U.S. Soyfoods Directory

Universidad de Jaén: Aceite de Oliva

University of Guelph: Meat Science: Growth and structure of meat animals

University of Texas: Meating place

University of Texas: Food Science and Techriology Animal

Science

USDA New Crops Research

\section{NORMALIZATION AND REGULATIONS}

Agriculture and Agri-Food Canada: Acts and Regulations Agriculture and Agri-Food Canada: Guide to food labelling and advertesiment

Asociación Española de Normalización y Certificación (AENOR) Boletin Oficial del Estado

Codex Alimentarius

Diario Oficial de la Generalitat de Catalunya

Foodnet Canada: Food Regulations

International Food Information Council: International Food

Regulation

International Organization for Standarization

Laboratori General d'Assaigs i Investigacions

Ministry of Agriculture, Fisheries and Food: Information on

Food

U.S. Food and Drug Administration Centre for Food Safety and http://vm.cfsan.fda.gov/ dms/qa-top.html Nutrition: Questions and answers:Food labelling

U.S. Food and Drug Administration Centre for Food Safety and http://vm.cfsan.fda.gov/ /rd/newlabel.html

Nutrition: Food labelling, nutrition and dietary supplement

information: overview of the next food label. http://www.agr.ca/dbse.html

http://www.agr.ca/misb/aisb/poultry/

http://www.aeb.org/

http://www.sheepusa.org/

http://www.meatami.org/

http://www.oilseeds.org/asa

http://sun20.cestel.es/aice/aice.html

http://www.cbef.com/

http://www.tuns.ca/ ciftweb/

http://www.corn.org/web/cornoil.htm

http://www.foodstuff.com/cgi-bin/gloss.cfm?alpha=A

http://www.gdch. de/dgf

http://www.readysoft.es/institutohuevo/

http://www.fishlink.co.uk/ifoma/

http://wwwsoc.nacsis.acjp/jocs/index-e.html

http://www.ag.uiuc.edu/ ks-qssb/welcome.html

http://www.medaccess.com/diet_guide/food1.htm

http://www.medilife.com/medilife/nutrition/index.html

http://www.mhr-viandes.com/fr/index.htm

http://www.beef.org/

http.://www.cottonseed.com/index.htm

http://www.oilseed.org/

http://www.nppc.org/

http://www.oilseeds.org/index.html

http://www.oliva.net/

http://porin.gov.my/

http://www.psa.uiuc.edu/

http://www.anr.ces.purdue.edu/anr/anr/swire/porkpage.ht

http://www.efr.hw.ac.uk/SDA/

http://www.soyfoods.com/foodsdescriptions/descriptions.ht http://www1.ujaen.es/ fespino/

http://www.aps.uoguelph.ca/ swatland/gasman.html

http://www.mtgplace.com/

http://savell-j.tamu.edu/ansc307h.html

http://www.ncaur.usda.gov/nc/nchome.htm

http://www.agr.ca/lawse.html

http://www.cfra-acia. agr.ca/english/food/label/home.html

http://www.aenor.es/

http://www.boe.es/

http://www. fao. org/waicent/faoinfo/economic/esn/codex/De

http://www.gencat.es/diari/

http://foodnet.fic.ca/

http://ificinfo.health.org/index15.htm

http://www.iso.ch/

http://www.lgai.es/

http://www.maff.gov.uk/food/foodindx.htm 
U.S. Food and Drug Administration Centre for Food Safety and http://vm.cfsan.fda.gov/ /rd/foodadd.html Nutrition: Food additves and Premarket Approval

U.S. Food and Drug Administration Centre for Food Safety and http://vm.cfsan.fda.gov/ dms/flg-toc.html Nutrition: Food industry and Importers: Food labelling guide

U.S. Food and Drug Administration Centre for Food Safety and http://vm.cfsan.fda.gov/ /rd/newlabel.html Nutrition: Food labelling, nutrition and dietary supplement information: overview of the next food label.

\section{NUTRITION AND DIETETICS}

American Society for Nutritional Sciences: Nutrient Information http://www.nutrition.org/nutinfo/ Austin Nutritional Research:

Basal Metabolism Calculator:

Diet Calculator:

Famous Arabidopsis Mutant Figure (U. Washington) Institute of Food Research (IFR): Science IFR: Nutrient metabolism and health

Institute of Food Research (IFR): Science IFR: Molecular mechanisms and genetic variation in response to food International Food Information Council: Cutting step by step Lipid Pathways:

Metabolic Pathways \& Genetic Maps: Enzyme nomenclature database "Expes"

Royal Society of Chemistry's Nutrition Page

Terre Haute Center form Medical Education-Medical

Biochemistry: Lipid Biochemistry

University of Akron: Dept. of Chemistry: The Hardy Research Group: Introducction to general, organic and biochemistry I and II: Lipids: Lipid and Aminoacid Metabolism

\section{UNIVERSITIES AND R+D CENTERS}

Acadia University: School of Nutrition \& Food Science Cornell University: Department of Food Science

CSIRO Division of Human Nutrition: Research Programs Department of Food Science and Technology of University of California, Davis

Department of Food Science Chalmers University of Technology

Institute National de la Recherche Agronomique

Institute of Food Research (IFR)

Institute of Food Technology of Hohenheim University

Instituto de la Grasa de Sevilla: Lineas de investigación y proyectos

Lund University: Vitamin Structures

Plan Nacional I+D: Consulta de base de datos de proyectos

Royal Veterinary \& Agricultural University: Center for avanced food studies

Royal Veterinary \& Agricultural University: Foodchemistry:

Projects: Department of Dairy and Food Science

Technical Research Centre of Finland: Biotechnology and Food Research

The University of Minnesota Omega 3 and 6 News On Line University of Alberta: Lipid and Lipoprotein Research group

University of Manitoba: Department of Food Science

University of Nebraska: Dept. of Food Science and Technology and The Food Processing Center

University of New South Wales: Department of Food Science and Technology

University of Queensland: Department of Food Science and

Technology

University of Reading: Department of Food Science and Technology http://www.realtime.net/anr/index.html http://www.room42.com/nutrition/basal.html http://www.techware.com/health/index.html http://www.wsu.edu:8080//BC/faculty/jb.thefig.html http://www.ifrn.bbsrc.ac.uk/buscom/ar96/nutrient.html

http://www.ifrn.bbsrc.ac.uk/buscom/ar96/molec_mech.html

http://ificinfo.health.org/index4.htm http://www.mcs.anl. gov/home/compbio/pathways/LIP. MPW/ http://exposy.heuge.ch/sprot/enzime.html

http://chemistry.rsc.org/rsc/nuts.htm http://www-isu.indstate.edu/theme/mwking/lipids.html

http://ull.chemistry.uakron.edu/classroom.html

http://ace.acadiau.ca/science/nutr/home.htm http://www.nysaes.cornell.edu/fst/ http://www.dhn.csiro.au/reprograms.html http://www-foodsci.ucdavis.edu/

http://www.sik.se/cth/english/eng_int.html

http://www.inra.fr/

http://www.ifrn.bbsrc.ac.uk/buscom/ar96/sensory.html http://www.uni-hohenheim.de/

http://www.ig.csic.es/

http://www.inl.lth.se/kurs/vitaminer.html http://www.cicyt.es/bdatos/wproys.htm http://www.bt.dtu.dk/lmc/lmc.htm

http://www.mli.kvl.dk/

http://www.vtt. fi/bel/

http://pufa.co.net/ http:www.lipidgroup.ualberta.ca/index.html http:www.umanitoba.ca/afs/food_science/ http://foodsci.unl.edu/fstfpc.asp

http://www.unsw.edu.au/foodsci/index.html

http://www.uq.oz.au/fst/

http://www.fst.rdg.ac.uk/index.htm 